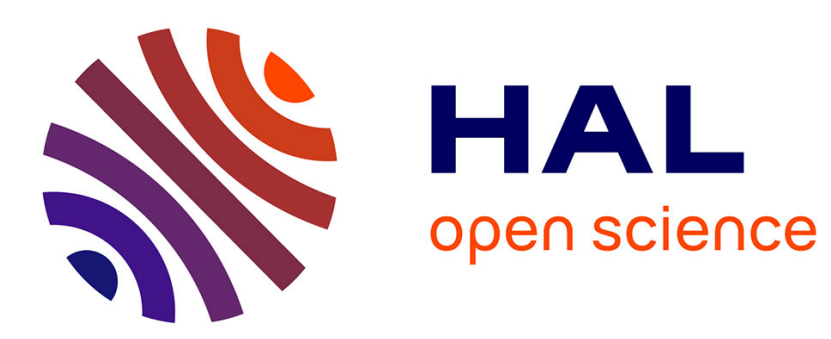

\title{
cross talk between epidermal growth factor (egf) receptor and extranuclear steroid receptors in cell lines
}

Antimo Migliaccio, Gabriella Castoria, Pia Giovannelli, Ferdinando Auricchio

\section{To cite this version:}

Antimo Migliaccio, Gabriella Castoria, Pia Giovannelli, Ferdinando Auricchio. cross talk between epidermal growth factor (egf) receptor and extranuclear steroid receptors in cell lines. Molecular and Cellular Endocrinology, 2010, 327 (1-2), pp.19. 10.1016/j.mce.2010.06.014 . hal-00613866

\section{HAL Id: hal-00613866 https://hal.science/hal-00613866}

Submitted on 7 Aug 2011

HAL is a multi-disciplinary open access archive for the deposit and dissemination of scientific research documents, whether they are published or not. The documents may come from teaching and research institutions in France or abroad, or from public or private research centers.
L'archive ouverte pluridisciplinaire HAL, est destinée au dépôt et à la diffusion de documents scientifiques de niveau recherche, publiés ou non, émanant des établissements d'enseignement et de recherche français ou étrangers, des laboratoires publics ou privés. 


\section{Accepted Manuscript}

Title: cross talk between epidermal growth factor (egf) receptor and extranuclear steroid receptors in cell lines

Authors: Antimo Migliaccio, Gabriella Castoria, Pia Giovannelli, Ferdinando Auricchio

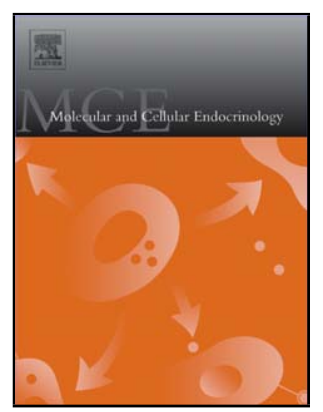

PII:

S0303-7207(10)00355-2

DOI: doi:10.1016/j.mce.2010.06.014

Reference: MCE 7581

To appear in: Molecular and Cellular Endocrinology

Received date:

21-4-2010

Revised date:

24-6-2010

Accepted date:

26-6-2010

Please cite this article as: Migliaccio, A., Castoria, G., Giovannelli, P., Auricchio, F., cross talk between epidermal growth factor (egf) receptor and extranuclear steroid receptors in cell lines, Molecular and Cellular Endocrinology (2010), doi:10.1016/j.mce.2010.06.014

This is a PDF file of an unedited manuscript that has been accepted for publication. As a service to our customers we are providing this early version of the manuscript. The manuscript will undergo copyediting, typesetting, and review of the resulting proof before it is published in its final form. Please note that during the production process errors may be discovered which could affect the content, and all legal disclaimers that apply to the journal pertain. 


\section{CROSS TALK BETWEEN EPIDERMAL GROWTH FACTOR (EGF) RECEPTOR AND} EXTRANUCLEAR STEROID RECEPTORS IN CELL LINES.

Antimo Migliaccio, Gabriella Castoria, Pia Giovannelli and Ferdinando Auricchio.

Department of General Pathology- /l Università di Napoli

Via L. De Crecchio, 7

80138 Napoli (ITALY)

Key words: EGF, EGF-R, steroid receptors, cross talk, Src-dependent signaling pathway. 


\section{ABSTRACT}

Steroid receptors act as ligand-dependent transcriptional factors. It has been observed that in addition to responding to cognate hormones with transcription activation, once hormone bound they are also capable of rapid responses following association with signaling effectors in the extra nuclear compartment. This novel aspect of steroid hormone action could influence our view of the cross talk between growth factor and steroid receptors. Increasing evidence shows that in hormone-responsive cells, a cross talk occurs between growth factors (EGF, IGF-1) and steroid hormone receptors that reciprocally regulate their action. To date, this has mostly been explained by modulation of steroid receptor transcriptional activity through growth factor receptor signaling activation. However, it is now known that growth factors might also act on extra nuclear steroid receptors, activating them via a hormone-independent mechanism. On the other hand, extranuclear steroid receptors can regulate growth factor receptor activity either directly interfering with their transduction pathways, or inducing autocrine growth factor secretion. Here we discuss findings indicating that EGF, like steroid hormones, induces association of steroid receptors with Src thereby activating pathways that can trigger cell proliferation and migration. Since mammary and prostate cancers respond to both steroid hormones and growth factors, this association might be a putative target for human cancer therapy. Findings from our laboratory supporting this view are discussed. 


\section{THE COMPLEX NETWORK OF EXTRA NUCLEAR INTERACTIONS OF STEROID RECEPTORS: THE EXAMPLE OF ESTROGEN RECEPTOR ALPHA}

Estrogen receptor/s (ERs) interact with a multitude of proteins inside as well as outside the nuclear compartment. Inside the nucleus, these receptors interact with hundreds of proteins that in different ways regulate ER transcriptional action (O'Malley, 2005). Outside the nucleus protein/protein interactions shape the signaling pathway followed by signal transduction from membrane to cell interior (Pawson, 2007).

Recent work from different laboratories shows that ERs located outside the nucleus activate different signal transduction pathways with multiple effects, such as cell growth and survival (Kousteni et al., 2001), cell migration (Giretti et al., 2008), and vasorelaxation (Simoncini et al., 2000). How can ERs, which unlike growth factor receptors are soluble and lack intrinsic enzyme activity, exert these stimulatory effects? The answer to this question is provided by a growing number of observations that once occupied by estradiol this receptor interacts with different signaling proteins and these interactions trigger signaling activity (for reviews, see Cato et al., 2002 and Levin, 2009). Such associations are facilitated by adaptor proteins and post-transcriptional modifications of the receptor. Signaling effectors interacting with the hormone-occupied receptor include the non-receptor-associated tyrosine kinase Src (Migliaccio et al., 2000), the p85alpha regulatory subunit of PI3K (Simoncini et al., 2000; Castoria et al., 2001), the adaptor protein SHC (Song et al., 2004), the focal adhesion kinase FAK (Le Romancer at al., 2008) and membrane receptor tyrosine kinases, such as EGF-R and erb-B2 (Fox et al., 2009). Interestingly, in the case of ERalpha/Src association the interacting sequences have been identified. Direct ERalpha/Src association triggered by estradiol occurs "in vitro". This suggests that ligand modification of receptor triggers its affinity for Src, most likely through allosteric modification. In addition an adaptor protein, p130 Cas, is involved in association of ERalpha with Src (Cabodi et al., 2004). Receptor modifications also play a key role in ER/Src association. ERalpha phosphorylation at tyrosine 537 is required for the direct interaction of ER with the Src-SH2 domain triggered by physiological concentration (10 nM) of estradiol (Migliaccio et al., 2000). In addition, it has recently been shown that ER arginine methylation regulates ER association with Src, p85 and FAK (Le Romacer at al., 2008). In conclusion, signal transduction pathway stimulation by estradiol requires ligand activation of the receptor, receptor modifications and adaptor proteins.

\section{EGF DIRECTS CROSS TALK BETWEEN EGF-R AND EXTRA NUCLEAR STEROID RECEPTORS}

Based on the knowledge that EGF-R shares many signaling effectors with the ER-activated pathway, we will present evidence that ER and androgen receptor (AR) not only participate in a large signalosome built around the EGF-R family kinases (IGFR, erb-B2, etc), but are required for EGF action in cells expressing ERs and AR. 
ERalpha and beta associate and cross talk with soluble receptors, AR and progesterone receptor B (PR-B) (Migliaccio et al., 2000; Migliaccio et al, 1998) as well as membrane receptors (Levin, 2005). Here we will focus on cross talk between EGF-R and extra nuclear ERalpha or beta in human mammary and prostate cancer-derived cells respectively. Many findings imply that ERs play a role in EGF signaling. Initial evidence comes from the observation that the estradiol antagonist Tamoxifen impairs EGF-induced DNA synthesis in breast cancer-derived MCF-7 cells (Vignon et al., 1987). It was later shown that EGF and IGF-1 lose the ability to induce proliferative markers in uterine epithelial cells of ER-knockout mouse (Hewitt et al., 2005; see also Table I). On the other hand, EGF is known to be involved in hormone-independent steroid receptor signaling in human cancer cells. EGF-R-related tyrosine kinase Erb-B2, was shown to be gene-amplified in 20$25 \%$ (Slamon et al 1989) of ER-positive breast cancers, and erb-B2 overexpression can cause Tamoxifen-stimulated growth as a mechanism of de novo resistance (Shou et al., 2004; Chung et al., 2002). This EGF-induced ER escape from hormone regulation could be explained by evidence that EGF triggers ligand-independent ER transcriptional activity through phosphorylation of specific critical residue(s) of nuclear estrogen receptor promoting interaction with its co-activator SRC1 (Schiff et al., 2003). EGF stimulates through MAPK-dependent signaling ERalpha serine phosphorylation on 118 (Kato et al., 1995) and 154 residues (Britton et al., 2008), likely enhances 305 serine phosphorylation (Rayala et al., 2006), and induces 167 serine phosphorylation through a PI3-K dependent pathway (Campbell et al., 2001). It has also been shown that EGF activated MAPK pathway can phosphorylate the ER coactivator AIB1 and nuclear co-repressor NCoR (Font de Mora \& Brown, 2000). Therefore, such phosphorylations triggered by growth factors lead to ligand-independent activation of ER transcriptional activity. This evidence seemed to point to a model where growth factors drive ER-regulated nuclear signaling through non-genomic pathways, thereby suggesting the existence of a unidirectional signaling flow from membrane to nuclear receptors (Figure 1). In turn, it was also observed that in breast cancer cells hormone-occupied ERalpha (Razandi et al., 2003), or a G protein-coupled receptor homologue (Filardo et al., 2000), promote EGF-R transactivation and downstream signaling through c-Src-mediated activation of the MMP cascade and subsequent release of membrane-associated heparin binding EGF (HB-EGF) (Fig. 2A).

We analyzed the impact of extra-nuclear ERalpha and beta on EGF signaling on the basis of our previous findings on these receptors. In MCF-7 cells, estradiol triggers association of ERalpha with $\mathrm{Src}$ and the regulatory subunit of PI3-K, p85alpha. This association activates a complex signaling network that stimulates G1-S transition through up-regulation of cyclin D1 and p27 nuclear release (Castoria et al., 2001; 2004). In MCF-7 cells, we also found that a small amount of ERalpha and AR (less than $10 \%$ of the total receptors) is associated under basal conditions. Therefore, either estradiol or androgen triggers association of both receptors with Src in these cells (Migliaccio et al., 2005). These findings could also explain the inhibition by antiandrogens of estradiol-stimulated Src activation as well as the inhibition by antiestrogens of androgen-stimulated Src activity. Therefore, we asked whether EGF acts in a similar way to estradiol or androgen in inducing both the 
assembly of multi-molecular complexes including ERalpha, AR and Src, and DNA synthesis. To evaluate this hypothesis, DNA synthesis was stimulated in quiescent MCF-7 cells with EGF; this stimulation was ER- and AR-dependent as it was suppressed by pure estradiol or androgen antagonists (ICI 182,780 or Casodex, respectively). Inhibition of EGF-induced DNA synthesis was also observed by ERalpha or AR silencing. Again, the Src inhibitor PP2 had a dramatic inhibitory effect on DNA synthesis elicited by EGF. Interestingly, ICI 182,780, Casodex and PP2 also abolished cytoskeletal changes induced by EGF. These findings suggest that in MCF-7 cells, EGF signaling depends entirely on ERalpha, AR and Src. This view was confirmed by the finding that, like estradiol and androgen, EGF induces rapid ERalpha/AR/Src association in these cells. A similar association was also induced by EGF in Cos cells ectopically expressing hERalpha and hAR (Migliaccio et al., 2005). In contrast, no association occurred when wild type hERalpha was substituted with mutant hERalpha containing a phenylalanine instead of tyrosine 537 , which is the only phosphorylated tyrosine residue of ERalpha in MCF-7 cells (Arnold et al., 1995).

Phosphotyrosine is required for interaction of ERalpha with the $\mathrm{Src}-\mathrm{SH} 2$ domain in cells stimulated by estradiol (Migliaccio et al., 2000). In MCF-7 cells, tyrosine phosphorylation of ERalpha is induced by EGF and is abolished by the inhibitor of EGF-R tyrosine kinase, Iressa, or Herceptin, the antibody directed against the external domain of erb-B2 (Migliaccio et al., 2005). From these data, we concluded that EGF treatment of MCF-7 cells through the EGF-R/erb-B2 complex induces phosphorylation on tyrosine 537 of AR-associated ERalpha (Migliaccio et al., 2005). Once hormone occupied, AR interacts in turn with the Src-SH3 domain (Migliaccio et al., 2000). Association between these proteins is triggered by EGF-induced ERalpha tyrosine phosphorylation as shown by co-immunoprecipitation of EGF-R, ERalpha, AR and Src. This complex triggers activation of Src and the Src-dependent pathway, which controls DNA synthesis and cell migration. Surprisingly, in addition to activating the Src/Ras/Erk pathway, the ERalpha/AR/Src signaling complex directs Src activity associated with ERalpha/AR on EGF-R. In fact, ICI 182,780, Casodex, or silencing of ERalpha, AR or the dominant negative form of Src strongly reduce EGF-R tyrosine phosphorylation. Experiments in Cos cells, which do not express AR or ER, confirm that ERalpha and AR up-regulate EGF-R tyrosine phosphorylation (Migliaccio et al., 2005). In fact, in these cells, ectopically expressed hERalpha and AR significantly increase EGF-R phosphorylation triggered by EGF.

Steroid receptors also play a key role in EGF action in a different hormone-dependent environment such as prostate cancer cells. LNCaP cells derive from human prostate cancer and are largely used to study androgen action. In addition to AR they express ERbeta, whose role in prostate cancer is debated (Imanov et al., 2004). A small percentage of the two receptors is associated under basal conditions and stimulation of LNCaP cells with estradiol or androgen triggers proliferation following AR/ERbeta/Src association and consequent Src-dependent pathway activation (Migliaccio et al., 2000). EGF stimulation of LNCaP cells also induces ERbeta/AR/Src association, Src activation, DNA synthesis and actin architectural changes. All these effects are 
inhibited by ICI 182,780 or Casodex. On this basis we concluded that, as in MCF-7 cells, EGF signaling also depends on extra nuclear steroid receptors in LNCaP cells (Migliaccio et al., 2000). These findings raise the question of whether other proteins also direct Src activity to EGF-R phosphorylation in cells not expressing ER and/or AR. Analysis of this aspect might reveal new EGF-signaling regulatory proteins. However, from the evidence described above and many other findings not described here it can be firmly established that a dynamic bi-directional interplay exists between EGF-R and steroid receptor signaling. Two different models of how this occurs can be envisaged and are briefly presented in Fig. 2. According to the model derived from Razandi et al., (2003) and shown in panel A, estradiol-bound ER activates EGFR activity by inducing metalloproteinase activation (MMP-9 and -2), which, in turn, causes HB-EGF secretion. HB-EGF transactivates EGFR to signal to ERK. MMP activation is mediated by Src kinase. In this model Src activation is mediated by $\mathrm{G}$ protein isoforms located at membranes. The mechanism of activation of these $\mathrm{G}$ proteins by ER needs to be further investigated. Interestingly, this model suggests that under some circumstances (e.g. in ER-negative cancer) other G protein-coupled receptors, such as the orphan receptor GPR 30 (Filardo et al., 2000; Vivacqua et al., 2009), might substitute ER in activating the EGFR-dependent pathway. Panel $B$ in the figure represents a model derived from our work and shows cross phosphorylation between two tyrosine kinases, EGFR and Src associated with ER. Ligand-activated EGFR phosphorylates ERalpha on tyrosine 537, inducing ER-Src association and kinase activation. Activated Src phoshorylates EGFR, amplifying receptor activity and inducing signal transduction activation. These two models show some substantial differences, and further analysis is required to assess whether they co-exist or work under different cell settings. Nevertheless, both of them clearly suggest that EGFR as well as ERalpha potentiate each other's activity and point to a key role of Src in cooperation between these receptors.

\subsection{EGF action on DNA synthesis is inhibited by interfering in steroid receptor-Src association through steroid receptor-derived peptides.}

The observation that in mammary and prostate cancer-derived cells estradiol and androgen or EGF can participate in the same transducesome to exert their proliferative and migratory action profoundly modifies our current view on the interplay between hormones and growth factors, and may have important therapeutic implications. Both steroid hormones and growth factors control progression of these cancers. Therefore, ERalpha/AR/Src association is a very promising target for specific approaches to mammary and prostate cancer therapy. The ERalpha phosphotyrosine 537, and probably the homologous ERbeta phosphotyrosine 443, is required for association of estradiol receptor alpha or beta with the Src-SH2 domain, whereas the 377-386 proline-rich sequence of AR interacts with the Src-SH3 domain (Migliaccio et al., 2000). We therefore synthesized small peptides derived from these sequences of the two receptors (Varricchio et al., 2007; Migliaccio et al., 2007). The peptides were expected to compete for Src association with the receptors, thereby 
inhibiting DNA synthesis induced by $10 \mathrm{nM}$ estradiol or R1881 treatment. The peptide derived from the sequence surrounding ERalpha phosphotyrosine 537 is a six-amino acid peptide (536-541), and was used in parallel with the non-phosphorylated form of the same peptide to evaluate the role of tyrosine phosphorylation in the Src-peptide interaction (Varricchio et al., 2007). In short-term experiments (up to 24 hours) the non-phosphorylated peptide had a much weaker inhibitory effect than that of the phosphorylated peptide, implying a dominant role of tyrosine phosphorylation. In long-term experiments, this difference disappeared. Use of the peptide with the same sequence, except for substitution of tyrosine with the non-phosphorylatable phenylalanine, restores the difference, suggesting that in long-term experiments the tyrosine residue of peptide undergoes phosphorylation. The peptides were amino-terminal acetylated and carboxyl-terminal amidated to reduce cleavage by exopeptidases. When MCF-7 cells or LNCaP cells were treated with 100 $\mathrm{ng} / \mathrm{mL}$ EGF, DNA synthesis was stimulated. Such a stimulation was abolished by ICI 182,780 and Casodex, as well as by nanomolar concentrations of the phosphorylated peptide (Varricchio et al., 2007) (Fig. 3, Panels A and B) This peptide also prevents DNA synthesis induced in the same cells by estradiol or androgen, indicating that EGF and steroid hormones share the mechanism triggering $S$ phase in estradiol- or androgen-stimulated cells. The phospho-peptide effect follows inhibition of ERalpha and AR association with Src, Src and Erk activation and induction of cyclin D1 expression in MCF-7 and LNCaP cells (Varricchio et al., 2007). The peptide has no effect on EGF-induced DNA synthesis in human mammary cancer-derived MDA-MB231 cells which express AR but not ER, indicating that the peptide specifically targets ER. The specificity of the proliferative inhibitory action is notably illustrated by the absence of inhibition by the phospho-peptide of estradiol-induced ERE-dependent transcriptional activity in MCF-7 cells. In these cells, protection from apoptosis induced by estradiol is inhibited by the phospho-peptide, widening the potential interest for the applicative aspects of this peptide (Varricchio et al., 2007).

Following a similar approach, we synthesized a peptide derived from the proline-rich 377-386 AR sequence interacting with the Src-SH3 domain. A peptide with the same amino acid composition but with a scrambled sequence was used in parallel experiments. This peptide shows a much weaker inhibitory effect than that of the 377-486 peptide, indicating that sequence rather than proline content plays a major role (Migliaccio et al., 2007). In LNCaP and MCF-7 cells, EGFinduced DNA synthesis was abolished by the peptide (Fig. 3, Panel C), which also inhibits S-phase entry induced by estradiol or androgen. Inhibition of the hormonal effect follows failure of AR/Src association, Src-dependent pathway activation and cyclin D1 expression. Furthermore, the peptide does not affect serum-induced DNA synthesis in LNCaP or MCF-7 cells, nor does it affect DNA synthesis or cytoskeletal changes triggered by EGF-activated Src in AR-negative prostate cancer DU145 cells (Migliaccio et al., 2007). This implies that the peptide specifically targets AR, without interfering in intrinsic Src activity. The peptide also prevents S-phase entry induced by androgen or EGF in AR-positive NIH3T3 fibroblasts (Castoria et al., 2003), thus reinforcing the view that AR is the target of the proline-rich peptide. In contrast with classic androgen antagonists, the peptide does not affect ARE-dependent transcriptional activity in LNCaP cells stimulated with androgen 
(Migliaccio et al., 2007). In addition to interfering with steroid/Src interaction, the phosphorylated and proline-rich peptides share some interesting properties: i) they rapidly penetrate across cell membrane, and within 30 min diffuse through the extra nuclear compartment of MCF-7 and LNCaP cells by a temperature-independent mechanism; ii) like anti-proliferative agents, they are active at very low concentration ( $1 \mathrm{nM}$ ) in MCF-7 and LNCaP cells; iii) unlike steroid antagonists, they do not affect receptor-dependent transcriptional activity; iv) unlike Src inhibitors, they do not interfere in intrinsic Src activity.

These promising properties led us to investigate the activity of these peptides in MCF-7 and LNCaP cell xenografts established in immunodepressed mice. Xenografts of MCF-7 cells were grown in ovariectomized and estrogen-stimulated mice intraperitoneally injected with the phosphorylated peptide. A dose-dependent inhibition of tumor growth was observed up to total suppression (Varricchio et al., 2007). In addition, xenografts of LNCaP cells were grown in intact male mice, which were treated with the proline-rich peptide. Here again, the peptide suppressed tumor growth. Immunohistochemistry of LNCaP xenografts showed a decrease in proliferative marker Ki67 and an increase in apoptotic cells in mice treated with the peptide, while no changes in body weight was detected (Migliaccio et al., 2007). Therefore, use of these molecules provides some potential advantages over conventional hormone antagonists and EGF inhibitors. They act downstream of ligand-receptor interaction and could even be effective in cancer cells bearing mutated receptors unable to bind hormones or growth factors. Furthermore, they are extremely selective in inhibiting only pathways potentially involved in deregulated growth without interfering with other effects of EGF or steroid hormones. Figure 3, panel D, summarizes the action of these molecules.

\section{CONCLUSIONS}

From findings by our and other laboratories it can be reasonably concluded that a continuous cross talk occurs between EGF-R family receptors and ER and AR. This cross talk does not only mean that growth factors can affect steroid-regulated gene expression and vice-versa, but it also exists at extra nuclear level, where EGF-R and steroid receptors can reciprocally and rapidly regulate activation of their transduction pathways. In particular, the observation that EGF-R requires steroid receptors in hormone-dependent cells raises some intriguing questions. Why, for example, does EGF-R need ER and/or AR expression to act on DNA synthesis in mammary and prostate cancer cells, whereas it is able to stimulate growth in many other cell types that do not express steroid receptors? It could be argued that the dependence of EGF-R signaling on steroid receptors represents a mechanism by which hormone-dependent cells recognize a hierarchy among signals regulating their functions, where the steroid hormones have a dominant role. In such a view it could be inferred that, when extra nuclear steroid receptors are down regulated or translocated to the nucleus, i.e. upon hormone stimulation, cell responsiveness to EGF goes to be also reduced. On the other hand it is conceivable that in different cell lines, devoid of ER or AR, other proteins such 
as estrogen-related receptor family members, which are almost ubiquitously expressed, might substitute steroid receptors in this regulatory role.

However, as previously shown, the observation of a direct cross talk between EGF and steroid receptors provides novel selective weapons in the treatment of hormone-dependent and independent cancers. It also worth noting that, in addition to associating with Src, activated ER and AR interact with other signaling effectors, which participate in a complex network controlling tumor progression. Once domains of steroid receptors involved in the interaction with these effectors have been revealed, it will become feasible to design other molecules (peptides or peptide derivatives) to inhibit growth and metastasis of tumors expressing steroid receptors. These custom-made drugs could be used in combination with the peptides described in the present article to improve the efficacy of tumor therapy. The increasing number of non-classical hormoneresponsive normal and cancer cells expressing steroid receptors, such as fibroblasts or colon cancer-derived cell lines (Castoria et al., 2003; Di Domenico et al. 1996), suggests that this therapeutic approach might be tried in a wide variety of human cancers. 


\section{LEGEND TO FIGURES}

Fig. 1. A model of EGF activation of steroid receptors located in the nucleus.

Fig. 2. Two models of ER-mediated EGF-R pathway activation.

The model proposed by Razandi et al. of E2-dependent ER-mediated transactivation of EGF-R is shown in A. Through a G-protein dependent mechanism, estradiol bound ER stimulates Src activity, which in turn activates metalloproteinases 2 and 9, increasing HB-EGF release. HB-EGF binds to EGF-R and activates its signaling.

The model reported by Migliaccio et al. of EGF-dependent, ER-Src mediated EGF-R activation is shown in B. EGF-activated EGF-R phosphorylates ERalpha on tyrosine 537, inducing ER-Src association and kinase activation. Activated Src phoshorylates EGF-R, amplifying receptor activity and its downstream targets inducing signal transduction activation.

Fig. 3. Effect of peptides inhibiting ER/AR/Src association on EGF-induced DNA synthesis.

In A, MCF-7 cells were stimulated with $100 \mathrm{ng} / \mathrm{mL}$ EGF alone or in presence of $10 \mu \mathrm{M} \mathrm{ICI} \mathrm{182,780}$ or $1 \mathrm{nM}$ of a six aa. peptide corresponding to the sequence 536-541 of ERalpha, including the phosphotyrosine 537 (PY pep), or a peptide with the same sequence but with unphosphorylated tyrosine. (Y pep). For comparison, cells were also stimulated with $10 \mathrm{nM} 17 \beta$ estradiol. BrdU incorporation was measured after $24 \mathrm{hrs}$ of treatment.

In $\mathrm{B}, \mathrm{LNCaP}$ cells were treated, as MCF-7 cells, with EGF alone, in the presence of PY pep, or $\mathrm{Y}$ pep. In these cells the EGF effect on DNA synthesis was compared with that of $10 \mathrm{nM}$ of synthetic androgen R1881.

In C, LNCaP cells were incubated with $100 \mathrm{ng} / \mathrm{mL}$ EGF alone, in the presence of $1 \mu \mathrm{M} \mathrm{ICI}$ $182,780,1 \mathrm{nM}$ of a peptide corresponding to the proline-rich sequence 377-386 of AR, (pro-pep), or a $1 \mathrm{nM}$ of peptide containing the same amino acid composition but with a scrambled sequence (c-pep).

In $\mathbf{D}$, a model of inhibitory action of receptor-derived peptides on EGF signaling is shown. In untreated cells EGF stimulates ER phosphorylation by EGFR, inducing the assembly of a ternary complex between ER, AR which is pre-associated with ER and Src. This induces Src activation, which phosphorylates EGFR activating the signaling cascade. The competitor peptides Y-Pep or pro-peptide, inhibit the formation of this complex by competing for binding of ER and AR to SH2 and $\mathrm{SH} 3$ domains of Src, respectively. In this way Src kinase fails to be activated and to phosphorylate EGFR. Therefore, the signaling activity is abolished. 


\section{ACKNOWLEDGEMENTS}

This work was supported by grants from Associazione Italiana per la Ricerca sul Cancro (National and Regional Grants to F.A. and A.M.). 


\section{REFERENCES}

Arnold, S.F., Obourn, J.D., Jaffe, H. and Notides, A.C., 1995. Phosphorylation of the human estrogen receptor on tyrosine 537 in vivo and by src family tyrosine kinases in vitro. Mol Endocrinol. 9, 24-33.

Britton, D. J., Scott, G. K., Schilling, B., Atsriku, C., Held, J. M., Gibson, B. W., Benz, C. C., and Baldwin, M. A. (2008) A novel serine phosphorylation site detected in the $\mathrm{N}$-terminal domain of estrogen receptor isolated from human breast cancer cells. J. Am. Soc. Mass Spectrom. 19, 729740

Cabodi, S., Moro, L., Baj, G., Smeriglio, M., Di Stefano, P., Gippone, S., Surico, N., Silengo, L., Turco, E., Tarone, G. and Defilippi, P., 2004. p130Cas interacts with estrogen receptor alpha and modulates non-genomic estrogen signaling in breast cancer cells. J Cell Sci. 117, 1603-1611.

Campbell, R.A., Bhat-Nakshatri, P, Patel, N.M., Constantinidou, D., Ali, S., Nakshatri H., 2001 Phosphatidylinositol 3-kinase/AKT-mediated activation of estrogen receptor alpha: a new model for anti-estrogen resistance. J Biol Chem. ;276, 9817-9824

Castoria, G., Lombardi, M., Barone, M. V., Bilancio, A., Di Domenico, M, Bottero, D., Vitale F., Migliaccio, A. and Auricchio, F., 2003. Androgen-stimulated DNA synthesis and cytoskeletal changes in fibroblasts by a nontranscriptional receptor action. J. Cell Biol. 161, 547-556.

Castoria, G., Migliaccio, A., Bilancio, A., Di Domenico, M., de Falco, A., Lombardi, M., Fiorentino, R, Varricchio L., Barone, M.V. and Auricchio, F., 2001. PI3-kinase in concert with Src promotes the S-phase entry of estradiol-stimulated MCF-7 cells. EMBO J. 20, 6050-6059.

Castoria, G., Migliaccio, A., Di Domenico, M., Lombardi, M., de Falco, A., Varricchio, L., Bilancio, A., Barone, M.V. and Auricchio, F., 2004. Role of atypical PKC in estradiol-triggered G1/S progression of MCF-7 cells. Mol. Cell. Biol. 24, 7643-7653.

Cato A.C., Nestl A., Mink S., 2002. Rapid actions of steroid receptors in cellular signaling pathways. Sci. STKE 138, RE9

Chung Y.L., Sheu M.L., Yang S.C., Lin C.H., Yen S.H., 2002. Resistance to tamoxifen-induced apoptosis is associated with direct interaction between Her2/neu and cell membrane estrogen receptor in breast cancer. Int J Cancer 97, 306-312

Di Domenico, M., Castoria, G., Bilancio, A., Migliaccio, A. and Auricchio, F., 1996. Estradiol activation of human colon carcinoma-derived Caco-2 cell growth. Cancer Res. 56, 4516-4521.

Filardo, E.J., Quinn, J.A., Bland, K.I., Frackelton, A.R. Jr., 2000. Estrogen-induced activation of Erk-1 and Erk-2 requires the G protein-coupled receptor homolog, GPR30, and occurs via trans- 
activation of the epidermal growth factor receptor through release of HB-EGF. Mol. Endocrinol. 14, 1649-1660.

Font de Mora, J. \& Brown, M., 2000. AIB1 is a conduit for kinase-mediated growth factor signaling to the estrogen receptor. Mol Cell. Biol., 20, 5041-5047.

Fox, E.M., Andrade J., Shupnik, M.A:, 2009. Novel actions of estrogen to promote proliferation: Integration of cytoplasmic and nuclear pathways. Steroids, 74, 622-627.

Giretti MS, Fu XD, De Rosa G, Sarotto I, Baldacci C, Garibaldi S, Mannella P, Biglia N, Sismondi $P$, Genazzani AR, Simoncini T. ,2008. Extra-nuclear signalling of estrogen receptor to breast cancer cytoskeletal remodelling, migration and invasion. PLoS One, 3, e2238

Hewitt, S.C., Harrell, J.C. and Korach, K.S., 2005. Lessons in estrogen biology from knockout and transgenic animals. Annu. Rev. Physiol. 67, 285-308.

Hurtado, A., Holmes, K.A., Geistlinger, T.R., Hutcheson, I.R., Nicholson, R.I., Brown, M., Jiang, J., Howat, W.J., Ali, S., and Caroll, J.S. 2008. Regulation of Erb-B2 by oestrogen receptor-PAX determines response to tamoxifen. Nature, 456, 663-666.

Ignar-Trowbridge, D.M., Nelson, K.G., Bidwell, M.C., Curtis, S.W., Washburn, T.F., McLachlan, J.A., Korach K.S., 1992. Coupling of dual signaling pathways: epidermal growth factor action involves the estrogen receptor. Proc. Natl. Acad. Sci. USA. 89, 4658-4662

Imamov, O, Lopatkin, N.A. and Gustafsson, J.A., 2004. Estrogen receptor beta in prostate cancer. N Engl J Med. 351, 2773-2774.

Kato, S., Endoh, H., Masuhiro, Y., Kitamoto, T., Uchiyama, S., Sasaki, H., Masushige, S., Gotoh, Y., Nishida, E., Kawashima, H., Metzger, D., Chambon, P 1995 Activation of the estrogen receptor through phosphorylation by mitogen-activated protein kinase. Science 270, 1491-1494

Kousteni, S, Bellido, T, Plotkin, L.I., O'Brien, C.A., Bodenner, D.L., Han, L, Han, K., Di Gregorio G.B., Katzenellenbogen, J.A., Katzenellenbogen, B.S., Roberson P.K., Weinstein R.S., Jilka R.L., Manolagas, S.C. 2001, Nongenotropic, sex-nonspecific signaling through the estrogen or androgen receptors: dissociation from transcriptional activity. Cell, 104, 719-730.

Le Romancer, M., Treilleux, I., Leconte, N., Robein-Lespinasse, Y., Sentis, S., BouchekiouaBouzaghou, K., Goddard, S., Gobert-Gosse, S. and Corbo, L., 2008. Regulation of estrogen rapid signaling through arginine methylation by PRMT1. Mol. Cell 31, 212-221.

Levin, E. R., 2005. Integration of the Extra nuclear and Nuclear Actions of Estrogen. Mol Endocrinol. 19, 1951-1959.

Levin, E. R., 2009. Plasma membrane estrogen receptors. Trends Endocrinol Metab. 20:477-82. 
Márquez, D.C., Lee, J., Lin T., Pietras, R.J., 2001. Epidermal growth factor receptor and tyrosine phosphorylation of estrogen receptor. Endocrine 16, 73-81

Migliaccio, A. , Di Domenico, M., Castoria, G., Nanayakkara, M., Lombardi, M., de Falco, A., Bilancio, A., Varricchio, L., Ciociola, A. and, Auricchio, F., 2005. Steroid receptor regulation of EGF signaling through Src in breast and prostate cancer cells: steroid antagonist action. Cancer Res. 65, 10585-10593.

Migliaccio, A., Castoria, G., Di Domenico, M., de Falco, A., Bilancio, A., Lombardi, M., Barone, M.V., Ametrano, D., Zannini, M.S., Abbondanza, C. and Auricchio, F., 2000. Steroid-induced androgen receptor-oestradiol receptor-beta Src complex triggers prostate cancer cell proliferation. EMBO J. 19, 5406-5417.

Migliaccio, A., Piccolo, D., Castoria, G., Di Domenico, M., Bilancio, A., Lombardi, M., Gong, W., Beato, M. and Auricchio, F., 1998, Activation of the Src/p21ras/Erk pathway by progesterone receptor via cross-talk with estrogen receptor. EMBO J. 17, 2008-2018.

Migliaccio, A., Varricchio, L., de Falco, A., Castoria, G., Arra, C., Yamaguchi, H., Ciociola, A., Lombardi, M., Di Stasio, R., Barbieri, A., Baldi, A., Barone, M.V., Appella, E. and Auricchio, F.,2007. Inhibition of the SH3 domain-mediated binding of Src to the androgen receptor and its effect on tumor growth. Oncogene 26, 6619-6629.

O'Malley, BW. 2005. A life-long search for the molecular pathways of steroid hormone action. Mol Endocrinol. 19, 1402-1411.

Pawson, T., 2007. Dynamic control of signaling by modular adaptor proteins. Curr Opin Cell Biol. $19,112-116$.

Pietras, R.J., Arboleda, J., Reese, D.M., Wongvipat, N., Pegram, M.D., Ramos, L., Gorman, C.M., Parker, M.G., Sliwkowski, M.X., Slamon D.J., 1995. HER-2 tyrosine kinase pathway targets estrogen receptor and promotes hormone-independent growth in human breast cancer cells. Oncogene. 15, 2435-2446.

Razandi, M., Pedram, A., Park, S.T., Levin, E.R., 2003. Proximal events in signaling by plasma membrane estrogen receptors. J Biol. Chem. 278, 2701-2712.

Rayala, S.K., Talukder, A.H., Balasenthil, S., Tharakan, R., Barnes, C.J., Wang, R.A., Aldaz, M., Khan, S., Kumar, R., 2006. P21-activated kinase1 regulation of estrogen receptor-activation involves serine 305 activation linked with serine 118 phosphorylation. Cancer Res. 66,1694-1701 
Schiff, R., Massarweh, S., Shou, J., and Osborne, C. K. Breast Cancer Endocrine Resistance: How Growth Factor Signaling and Estrogen Receptor Coregulators Modulate Response. Clin. Cancer Res. 2003 9, 447s-454s

Shou, J., Massarweh, S., Osborne, C.K., Wakeling, A.E., Ali, S., Weiss, H., Schiff, R., 2004. Mechanisms of tamoxifen resistance: increased estrogen receptor-HER2/neu cross-talk in ER/HER2-positive breast cancer. J. Natl. Cancer. Inst. 96, 926-935

Simoncini, T., Hafezi-Moghadam, A., Brazil, D.P., Ley, K., Chin, W.W. and Liao, J.K., 2000. Interaction of oestrogen receptor with the regulatory subunit of phosphatidylinositol-3-OH kinase. Nature 407, 538-541.

Slamon, D.J., Godolphin, W., Jones, L.A., Holt, J.A., Wong, SG, Keith, DE, Levin, WJ, Stuart SG, Udove J, Ullrich A, Press MF., 1989. Studies of the HER-2/neu proto-oncogene in human breast and ovarian cancer. Science $244,707-712$.

Song, R., Barnes C., Zhang, Z., Bao, Y., Kumar, R., and Santen, R., 2004. The role of Shc and insulin-like growth factor 1 receptor in mediating the translocation of estrogen receptor alpha to the plasma membrane. Proc Natl Acad Sci U S A., 101, 2076- 2081.

Varricchio, L., Migliaccio, A., Castoria, G., Yamaguchi, H., de Falco, A, Di Domenico, M., Giovannelli, P., Farrar, W., Appella, E. and Auricchio, F., 2007. Inhibition of Estradiol Receptor/Src Association and Cell Growth by an Estradiol Receptor \{alpha\} Tyrosine-Phosphorylated Peptide. Mol Cancer Res. 11, 1213-1221.

Vignon, F., Bouton, M.M. and Rochefort, H., 1987. Antiestrogens inhibit the mitogenic effect of growth factors on breast cancer cells in the total absence of estrogens. Biochem Biophys Res Commun. 146, 1502-1508.

Vivacqua, A., Lappano, R., De Marco, P., Sisci, D., Aquila, S., De Amicis, F., Fuqua, S.A., Andò, S., Maggiolini, M., 2009. G protein-coupled receptor 30 expression is up-regulated by EGF and TGF alpha in estrogen receptor alpha-positive cancer cells. Mol. Endocrinol., 23, 1815-1826. 
Table I. Evidence of cross talk between EGF-R/erb-B2 and ER

\begin{tabular}{|c|c|}
\hline $\begin{array}{l}\text { EGF-induced DNA synthesis is } \\
\text { blocked by antiestrogens in } \\
\text { breast cancer MCF- } 7 \text { cells }\end{array}$ & Vignon et al., 1987 \\
\hline $\begin{array}{l}\text { EGF enhances ERalpha nuclear } \\
\text { localization and DNA synthesis in } \\
\text { mouse uterus }\end{array}$ & Ignar-Towbridge et al., 1992 \\
\hline $\begin{array}{l}\text { Heregulin induces tyrosine } \\
\text { phosphorylation of ERalpha, } \\
\text { ERalpha/ERE association and } \\
\text { PgR induction in MCF-7 cells }\end{array}$ & Pietras et al., 1995 \\
\hline $\begin{array}{l}\text { EGF stimulates ER tyrosine } \\
\text { phosphorylation and EGF-R/ER } \\
\text { coimmunoprecipitation in MCF-7 } \\
\text { cells }\end{array}$ & Marquez et a \\
\hline $\begin{array}{l}\text { EGF requires ERalpha for } \\
\text { epithelial cell proliferation in } \\
\text { mouse uterus epithelial cells }\end{array}$ & Hewitt et al., 2005 \\
\hline $\begin{array}{l}\text { Erb-B2 transcription is repressed } \\
\text { by ERalpha }\end{array}$ & Hurtado et al., 2008 \\
\hline
\end{tabular}




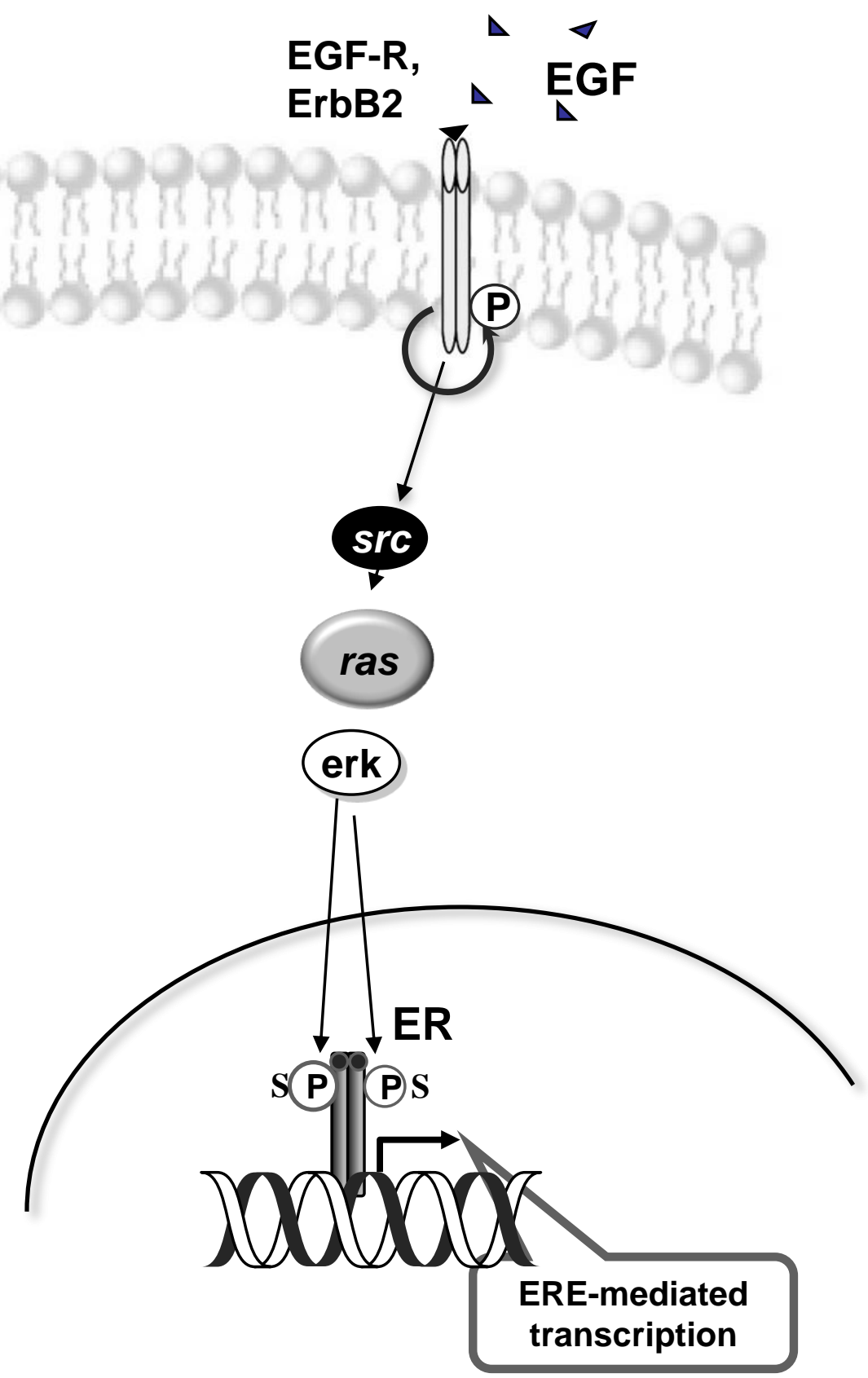


A $\bullet$

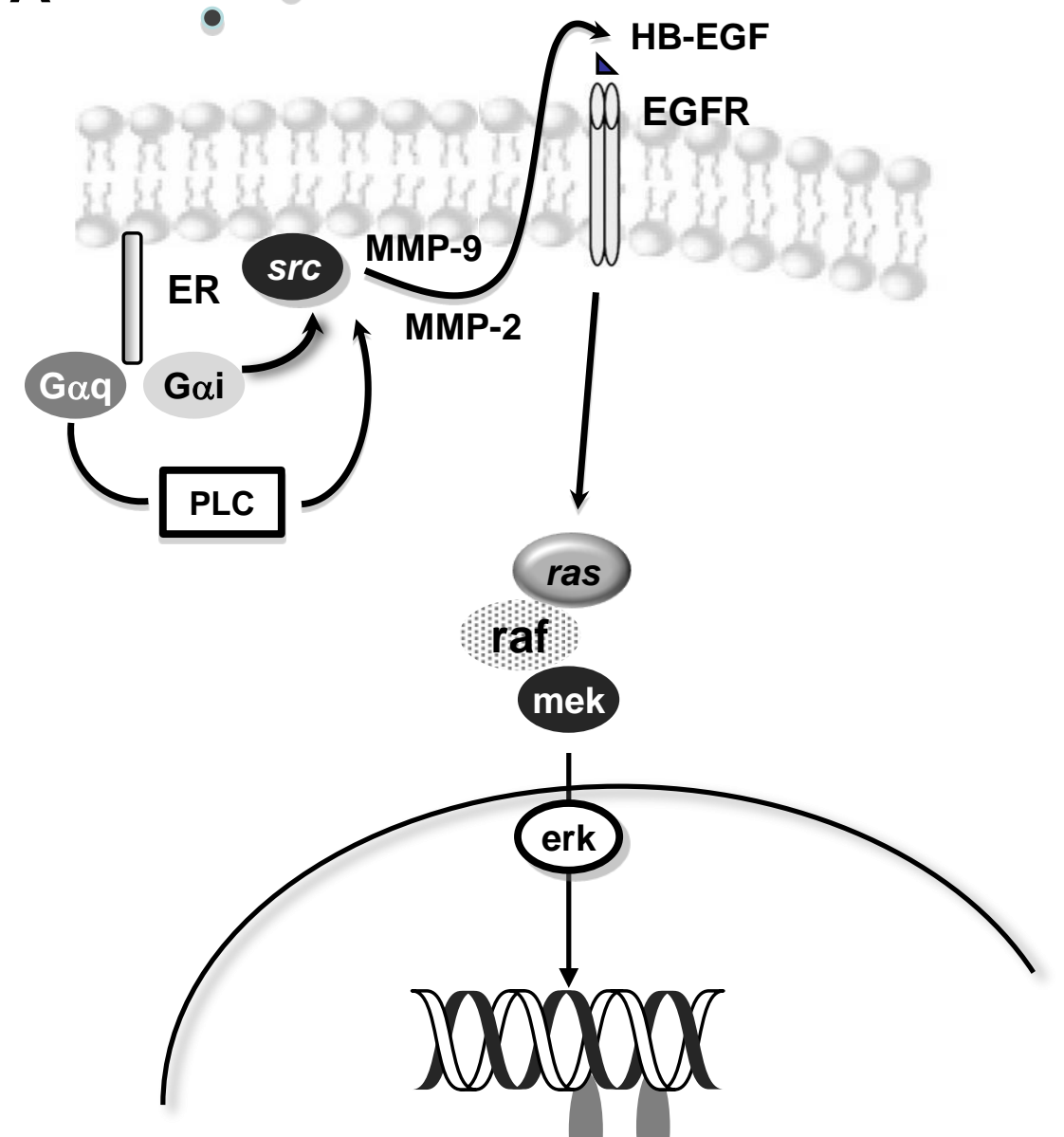

SRF mediated transcription

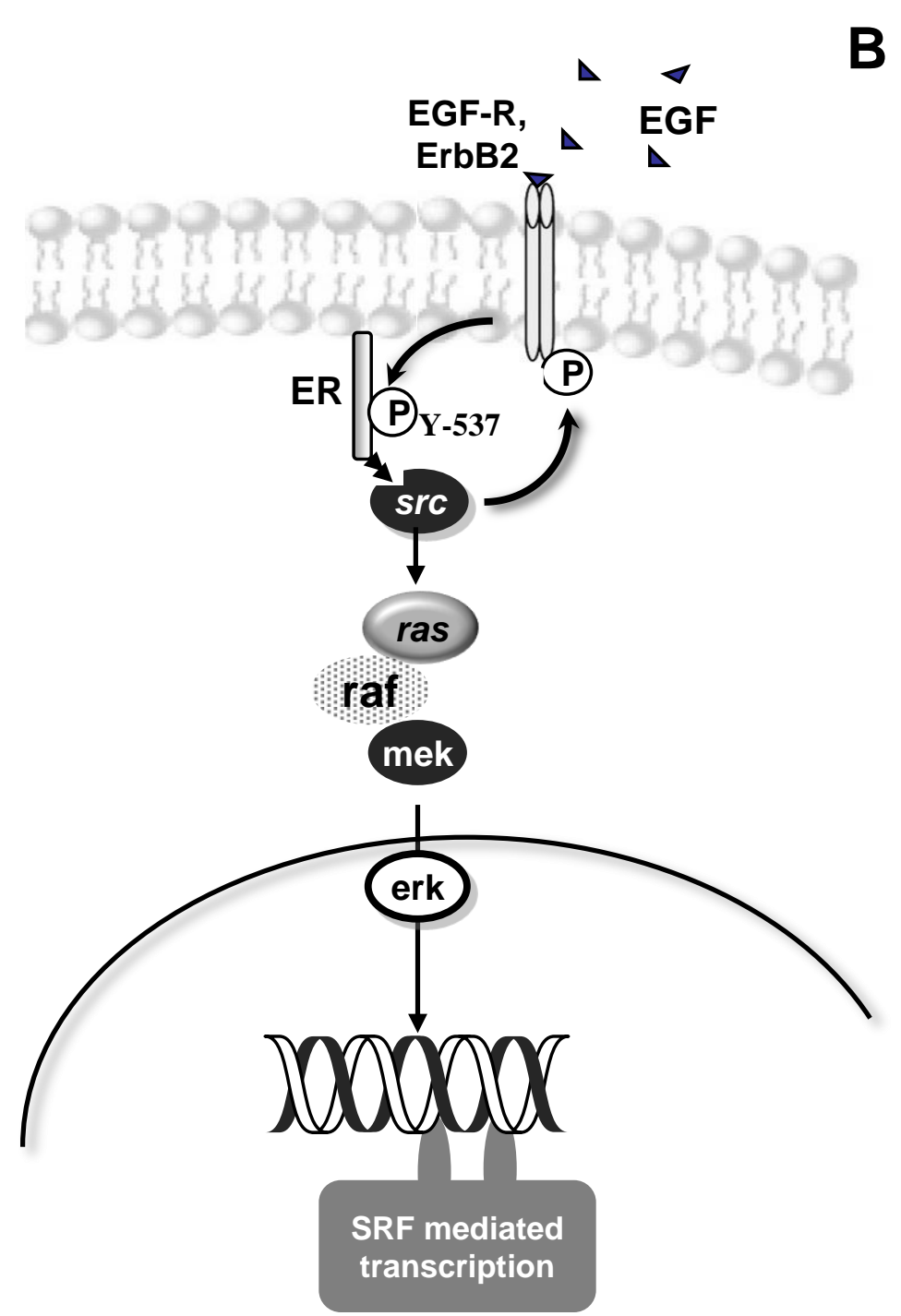




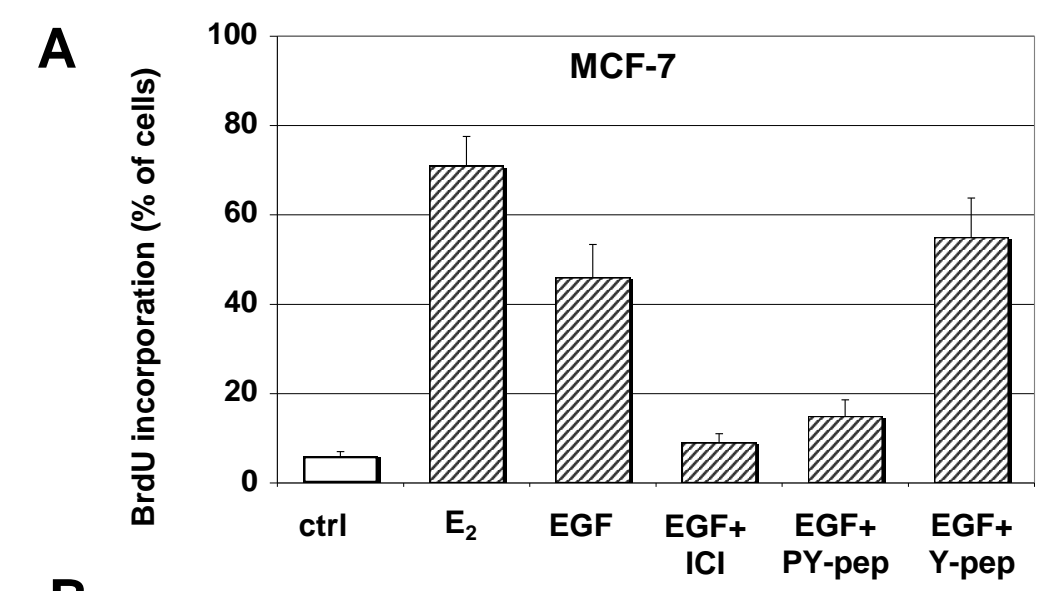

B

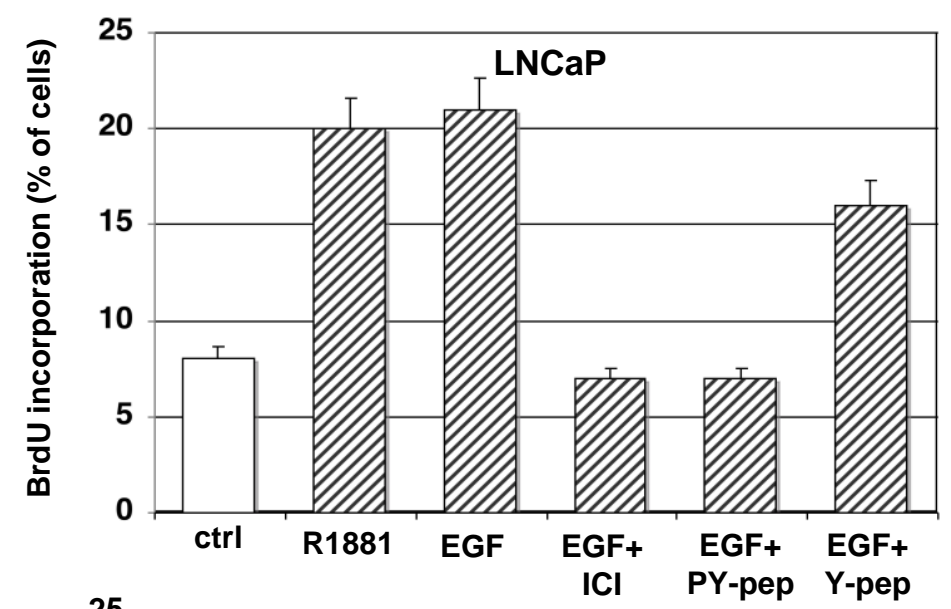

C

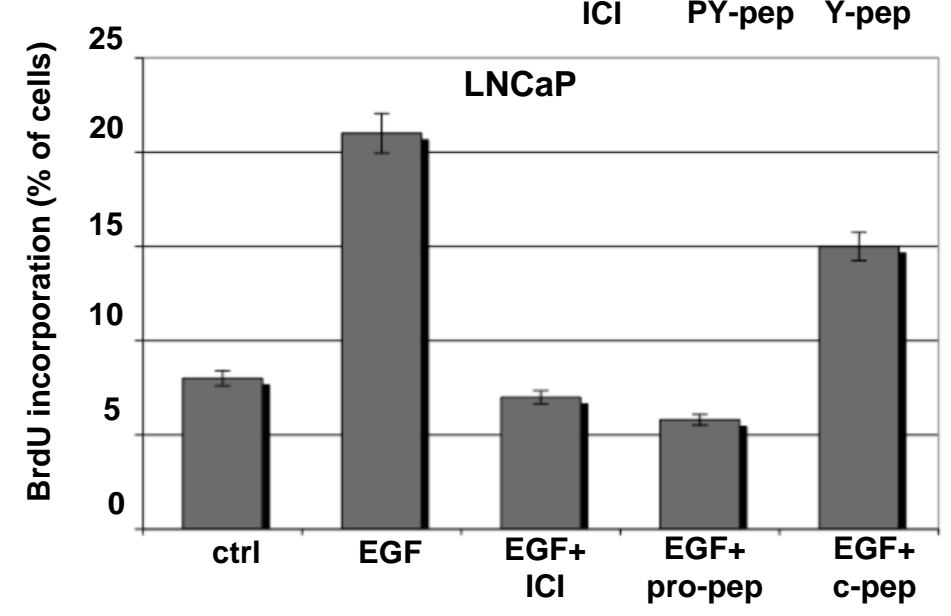

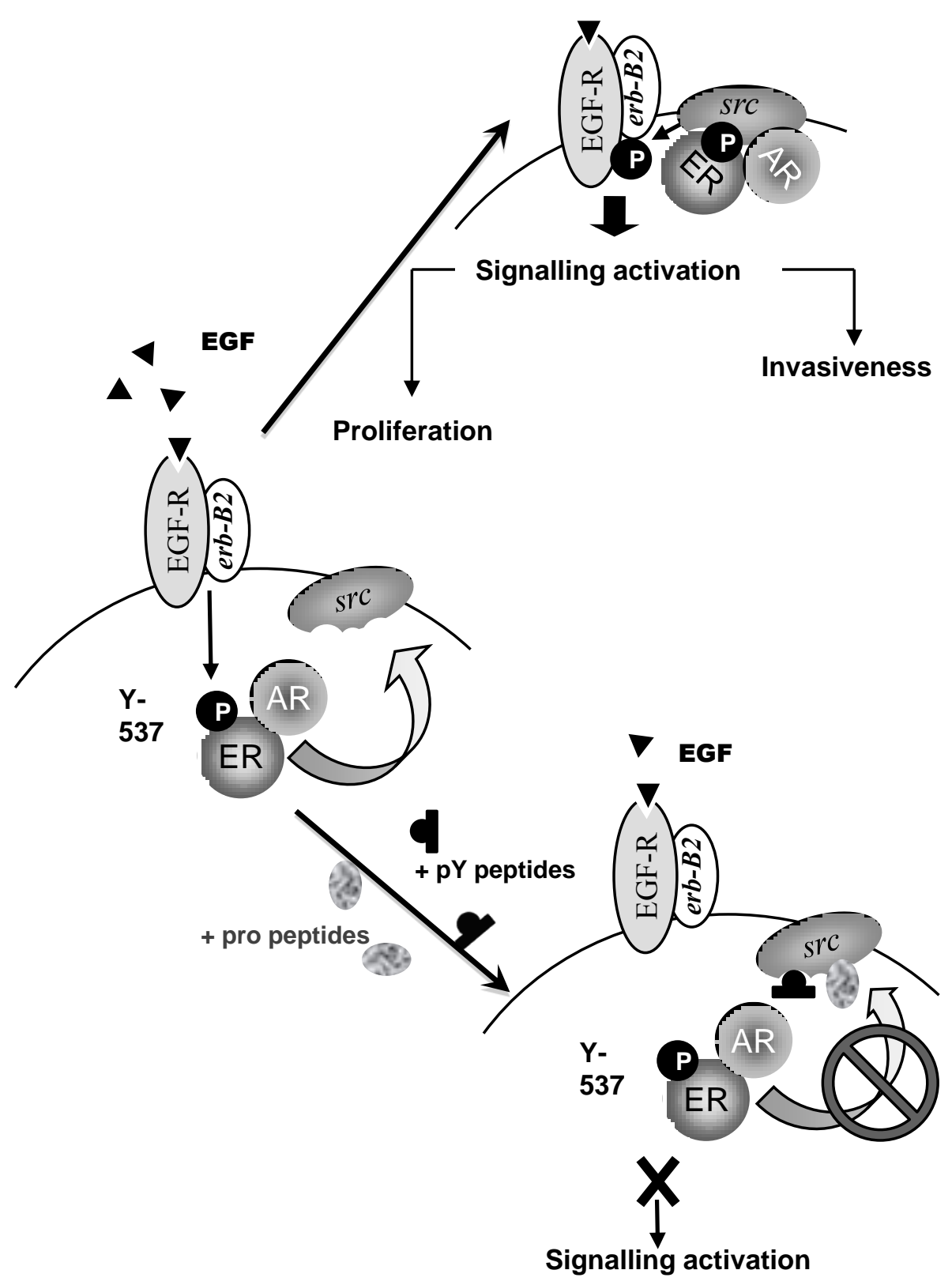

